\title{
Impact of Planting Windows on Growth, Yield and Economics of Potato Production under Climate Change Scenario in Central India
}

\author{
S. P. Singh ${ }^{*}$ \\ Division of Crop Production, ICAR-Central Potato Research Station, Maharajpura, Gwalior, Madhya Pradesh (474 020), India
}

\section{Article History}

Manuscript No. AR1430a

Received in $8^{\text {th }}$ August, 2015

Received in revised form $22^{\text {nd }}$ July, 2016

Accepted in final form $5^{\text {th }}$ August, 2016

\section{Correspondence to}

*E-mail: drshivpratapsingh@yahoo.co.in

\section{Keywords}

Planting window, $\mathrm{N}$ use efficiency, water use efficiency

\begin{abstract}
A field experiment was conducted to study adaptation of potato to climate aberrations at Central Potato Research Station, Gwalior, India which is located in Central Plains of India. Potato cultivar Kufri Jyoti was planted with five planting windows (planting dates) viz $15^{\text {th }}$ September, $30^{\text {th }}$ September, $15^{\text {th }}$ October, $30^{\text {th }}$ October and $15^{\text {th }}$ November for two consecutive years during 2009-10 and 2010-11. Treatments were replicated four times. Early planting at higher temperature delayed tuberization, reduced tuber number $(1,80,399)$ and finally there was drastic reduction in tuber yields $\left(11.4 \mathrm{t} \mathrm{ha}^{-1}\right)$. Highest tuber yield (31.6 $\left.\mathrm{t} \mathrm{ha}^{-1}\right)$ was recorded with $15^{\text {th }}$ October planted crop which was significantly higher over early planting windows. Net returns were negative in $15^{\text {th }}$ and $30^{\text {th }}$ September planting windows due to reduction in tuber yields. Highest $\mathrm{N}$ uptake $\left(92 \mathrm{~kg} \mathrm{ha}^{-1}\right)$ was recorded with $15^{\text {th }}$ October planted crop however it was lowest with $15^{\text {th }}$ September planted crop. Highest water use efficiency (126 kg tuber/ $\mathrm{mm}^{-1}$ water) was also recorded with the same treatment because of higher tuber yield and lesser evapo-transpiration demand during crop growth period. Delayed planting of $15^{\text {th }}$ November also reduced tuber yield due to increased temperature at the active bulking period of the potato. Thus, $15^{\text {th }}$ October planting window is most suitable date for planting ware potato crop for the region to get good yield, net returns and increase input use efficiency.
\end{abstract}

\section{Introduction}

Climate change will affect the production of crops like potato, which are sensitive to water shortages. Predicted fluctuations in weather during the next 50 years include frequent extreme temperatures and increasing drought in a number of important crop production regions (Jaggard et al., 2010). Change in composition of GHG-green house gases viz., $\mathrm{CO}_{2}, \mathrm{CH}_{4}, \mathrm{~N}_{2} \mathrm{O}$ and chlorofluorocarbons leads to increased temperature which in turn has impact on the world climate, leading to the phenomena known as climate change. If we look to potato, it has been thermo-sensitive and were only productive under long day conditions in temperate climate. But development of heat tolerant cultivars and adjustment in production system management has made it possible to have very high productivity in subtropical and warmer climate. Global potential potato yield decreases by $18 \%$ to $32 \%$ (without adaptation) and by $9 \%$ to $18 \%$ (with adaptation). Shifting planting time or location is less feasible at lower latitudes, and in these regions global warming could have a strong negative effect on potato production. It is shown that heat-tolerant potato cultivars could be used to mitigate effects of global warming in (sub) tropical regions (Hijmans, 2003).

Temperature controls the plant growth, development and yield and day degrees are normally used to quantify its effect. The partitioning of dry matter into the different organs viz. leaves, stems and roots has been found to be a function of development stage which inturn is a function of accumulated heat units. Relationships between P- days (modified from growing degree days) and the proportion of dry madder accumulation (DMA) in different plant parts have great potential to serve as a simple method of quantifying the effect of temperature on dry matter partitioning and thus on yields (Knowles and Knowles, 2006). Strategies like changing planting dates in order to combat the likely increase in temperature and water stress periods during the crop growing season.

To address the adverse impacts of climate change on productivity and quality of crops we need to develop sound adaptation strategies. Small changes in climatic parameters can often be managed reasonably well by altering date of planting, spacing and input management. 


\section{Materials and Methods}

A field experiment was conducted to study adaptation of potato to climate aberrations at Central Potato Research Station, Gwalior, India which is located in Central Plains at $26^{\circ} \mathrm{N}$ and $78^{\circ} \mathrm{E}$ and $207 \mathrm{~m}$ amsl. Potato cultivar Kufri Jyoti was planted with five sowing windows (planting dates) viz $15^{\text {th }}$ September, $30^{\text {th }}$ September, $15^{\text {th }}$ October, $30^{\text {th }}$ October and $15^{\text {th }}$ November for two consecutive years during 2009-10 and 2010-11. Treatments were replicated four times. The soil of the experimental site was silty clay loam, low in organic carbon (0.33\%), available $\mathrm{N}(149)$ and $\mathrm{P}(9.97)$ and medium in available $\mathrm{K}\left(280 \mathrm{~kg} \mathrm{ha}^{-1}\right)$ with $\mathrm{pH}$ of 6.7 . Well sprouted medium size seed tubers $(30-35 \mathrm{~g})$ were planted at $60 \times 20 \mathrm{~cm}^{2}$ spacing in the ridges at a depth of $5-7 \mathrm{~cm}$ so that tuber mergence start at 8-10 days after planting (DAP). Recommended doses of N, P and K were applied @ 180:34.9:100 kg ha ${ }^{-1}$, respectively. Fifty percent $\mathrm{N}$ through ammonium sulphate and full doses of $\mathrm{P}$ and $\mathrm{K}$ were applied through single super phosphate and muriate of potash, respectively at planting. Remaining half dose of $\mathrm{N}$ was applied through urea at earthing up. Earthing up was done after weeding at 25 DAP.

Irrigation was applied through furrow method at an interval of 8-10 days in first two date of plantings initially and $12-15$ DAP later when temperature became cool. The quantification of irrigation water applied was measured using depth -interval method. All the standard cultural and plant protection practices were followed as per recommended schedules to raise a stress free crop. Destructive plant sampling and computations of total fresh weights were done at 10 days interval starting from 25 DAP to 90 DAP. At each sampling fresh weight of leaves, stems and easily recoverable roots were recorded from 5 plants per plot. Dehaulming was done manually at 90 days after planting (DAP) as per treatments and harvesting was done two weeks later on skin suberization. The plant stand was monitored from 12 DAP till constant emergence. Leaf area index (LAI) was recorded with the help of Ceptometer (AccuPar model
LP-80) at 65 DAP. Meteorological data were obtained from the meteorological observatory (Table 1). Soil samples were collected from $0-15 \mathrm{~cm}$ depth before planting during first year and at harvest of crop and were analyzed for OC and Available N. Economics were computed using the prevailing market prices for inputs and out puts. The standard analytical method was used for determination of nutrient $\mathrm{N}$ by alkaline permanganate method. The nitrogen use efficiency ( $\mathrm{kg}$ tuber $\mathrm{kg}^{-1} \mathrm{~N}$ applied) was calculated by dividing the tuber yield with applied N. Nitrogen content and uptake by potato were analysed through prescribed laboratory procedure. Water use efficiency was also worked out using the following formula:

$$
\text { WUE }=\frac{\text { Tuber yield }\left(\mathrm{kg} \mathrm{ha}^{-1}\right)}{\text { Water applied through irrigation }(\mathrm{mm})}
$$

\section{Results and Discussion}

\subsection{Growth and yield attribute}

Establishment of optimum plant population was one of the great challenge in extra early planted crop. Leaf area index recorded at 65 DAP showed significant variation at different windows. Highest leaf area index was recorded with $15^{\text {th }}$ October planted crop which was followed by $15^{\text {th }}$ September planted crop (Table 2). Mean leaf fresh weight $\left(\mathrm{g} \mathrm{plant}^{-1}\right)$ was highest (76.4) with $30^{\text {th }}$ October planted crop which was closely followed by $15^{\text {th }}$ October planted crop. Leaf fresh weight increased from 25 DAP to 75 DAP thereafter there was no increase in leaf fresh weight. Highest leaf fresh weight $(76.4 \mathrm{~g})$ was recorded at 75 DAP with $30^{\text {th }}$ October planted crop. Highest root fresh weight was recorded with $15^{\text {th }}$ November planted crop. Lowest root weight was recorded with $30^{\text {th }}$ September planted crop. Highest stem weight $\left(53.9\right.$ g plant $\left.^{-1}\right)$ was recorded with $30^{\text {th }}$ October planted crop which was closely followed by $15^{\text {th }}$ October planted crop. Rapid establishment of leaf area for early capture of solar radiation is essential for optimizing final tuber yield and dry matter content (Pavek and Thornton, 2009). Stem fresh weight increased up to 55 days and thereafter there was no increase

Table 1: Monthly meteorological parameters during the crop seasons

\begin{tabular}{|c|c|c|c|c|c|c|c|c|c|c|}
\hline \multirow{3}{*}{ Month } & \multicolumn{5}{|c|}{$2009-10$} & \multicolumn{5}{|c|}{$2010-11$} \\
\hline & \multicolumn{3}{|c|}{$\begin{array}{l}\text { Monthly mean air temperature } \\
\left({ }^{\circ} \mathrm{C}\right)\end{array}$} & \multirow[t]{2}{*}{$\begin{array}{l}\text { Monthly } \\
\text { SS (hr) }\end{array}$} & \multirow{2}{*}{$\begin{array}{c}\text { Monthly } \\
\text { rainfall } \\
(\mathrm{mm})\end{array}$} & \multicolumn{3}{|c|}{$\begin{array}{l}\text { Monthly mean air temperature } \\
\qquad\left({ }^{\circ} \mathrm{C}\right)\end{array}$} & \multirow[t]{2}{*}{$\begin{array}{l}\text { Monthly } \\
\text { SS (hr) }\end{array}$} & \multirow{2}{*}{$\begin{array}{l}\text { Monthly } \\
\text { rainfall } \\
(\mathrm{mm})\end{array}$} \\
\hline & Max. & Min. & mean & & & Max. & Min. & mean & & \\
\hline $15-30^{\text {th }} \mathrm{Sep}$ & 34.3 & 24.1 & 29.2 & 231.7 & 31 & 32.4 & 24.3 & 28.4 & 163.9 & 35.1 \\
\hline October & 32.8 & 19.5 & 26.2 & 227.4 & 171 & 33.8 & 18.6 & 26.2 & 237.5 & 0 \\
\hline November & 28.5 & 12.9 & 20.7 & 192.3 & 14 & 27.8 & 12.5 & 20.2 & 123.2 & 8.8 \\
\hline December & 24.2 & 9.35 & 16.8 & 191.7 & 10.4 & 23.2 & 6.8 & 15.0 & 213.6 & 8.1 \\
\hline January & 19.3 & 4.9 & 12.1 & 168.6 & 0.0 & 20.6 & 5.3 & 13.0 & 215.6 & 0.0 \\
\hline $1-15^{\text {th }} \mathrm{Feb}$ & 26.9 & 10.6 & 18.8 & 117.3 & 1.3 & 26.05 & 5.0 & 15.5 & 89.6 & 1.1 \\
\hline
\end{tabular}

SS: Sun shine hours 
in fresh weight of stem in $15^{\text {th }}$ September and $30^{\text {th }}$ September planted crop however, it increased up to 75 DAP in $15^{\text {th }}$ and $30^{\text {th }}$ October crops. Leaves Dry weight $(\mathrm{g})$ plant $^{-1}$ showed increase up to 65 DAP in $20^{\text {th }}$ September planted crop, up to 75 DAP in $30^{\text {th }}$ September planted crop and up to 85 DAP in $20^{\text {th }}$ and $30^{\text {th }}$ October planted crops (Figure 1). Per plant stem dry weight $(\mathrm{g})$ in general increased from planting until 85 DAP (Figure 2). Per plant root dry weight (g) increased up to 65 DAP and there after declined til maturity (Figure 3). Almost

Leaf dry weight plant ${ }^{-1}$

$\rightarrow 15^{\text {th }}$ September $\rightarrow-30^{\text {th }}$ September $\rightarrow 15^{\text {th }}$ November $* 30^{\text {th }}$ October $* 15^{\text {th }}$ November

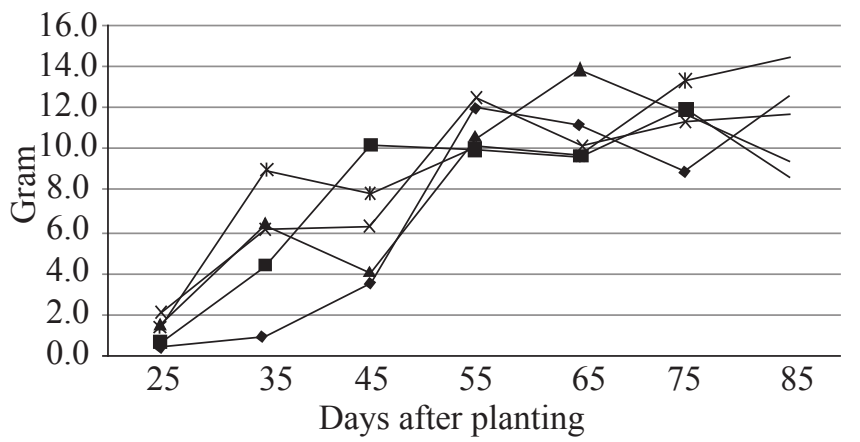

Figure 1: Leaf dry weight plant ${ }^{-1}$

Stem dry weight plant ${ }^{-1}$

$\rightarrow 15^{\text {th }}$ September $-30^{\text {th }}$ September $* 15^{\text {th }}$ October

$* 30^{\text {th }}$ October $* 15^{\text {th }}$ November

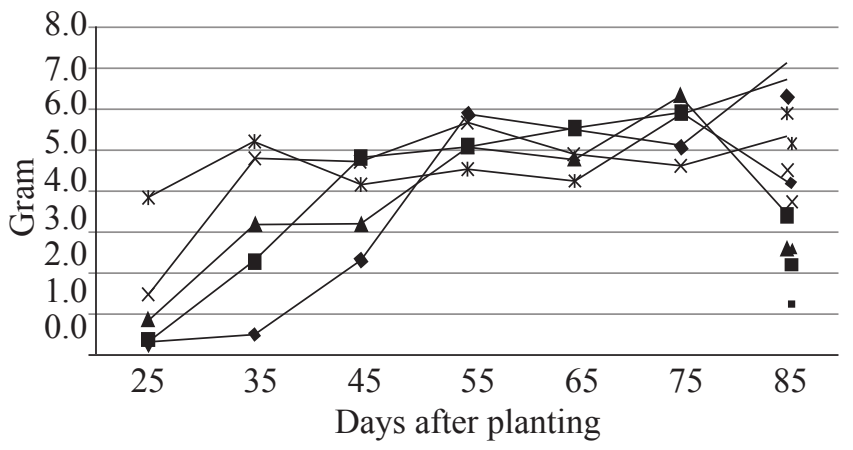

Figure 2: Stem dry weight plant $^{-1}$

Root dry weight plant ${ }^{-1}$

$-15^{\text {th }}$ september $\rightarrow 30^{\text {th }}$ september $\rightarrow 15^{\text {th }}$ October

$* 30^{\text {th }}$ October $* 15^{\text {th }}$ November

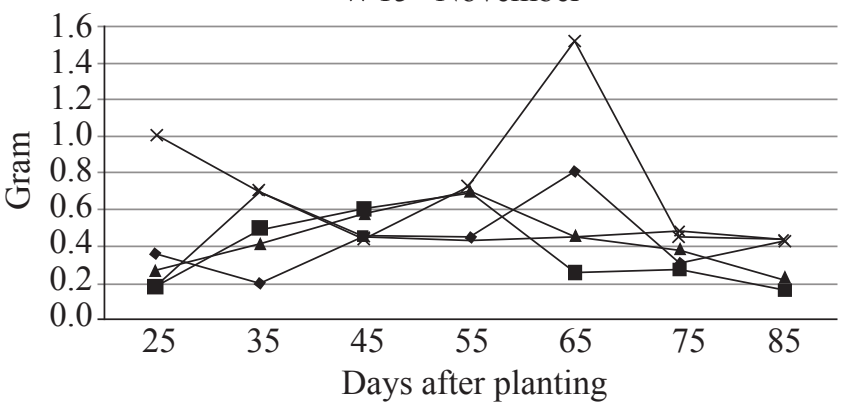

Figure 3: Root dry weight plant ${ }^{-1}$ similar leaf dry weight plant ${ }^{-1}$ was recorded at 75 DAP in $30^{\text {th }}$ September and $10^{\text {th }}$ and $20^{\text {th }}$ October planted crops. Gain in leaf and stem dry weight was faster in $10^{\text {th }}$ October planted crop, however, in case of root weight it was with $20^{\text {th }}$ October crop.Excessive canopy growth rate in the season extends tuber bulking and delay plant maturity which ultimately results in reduced tuber yield. On the other hand, an under sized canopy that senescesprematurely is likely to result in a loss of potential yield (Knowles and Knowles, 2006).

\subsection{Number of tubers}

Highest number of small size tubers $\left(1,72,440 \mathrm{ha}^{-1}\right)$ were recorded with $15^{\text {th }}$ October planted crop which were significantly higher over $15^{\text {th }}$ and $30^{\text {th }}$ September planted crop but on par with other windows. Highest number of medium size tubers $\left(1,70,282 \mathrm{ha}^{-1}\right)$ was recorded with $15^{\text {th }}$ October planted crop which was significantly higher over $15^{\text {th }}$ and $30^{\text {th }}$ September planted crop. Pavek and Thornton 2009 also reported tuber number plant ${ }^{-1}$ can be influenced by temperature, soil moisture, plant health, planting depth, physiological age of tuber, soil fertility and irradiance. Production of medium size tubers was statistically on par with $15^{\text {th }}$ October, $30^{\text {th }}$ October and $15^{\text {th }}$ November planted crops. Highest number of large size tubers $\left(1,02,580 \mathrm{ha}^{-1}\right)$ was recorded with $15^{\text {th }}$ October planted crop which was significantly higher than all other windows. Highest total number of tubers $\left(4,45,302 \mathrm{ha}^{-1}\right)$ was recorded with $15^{\text {th }}$ October planted crop which was significantly higher over all other windows. Lower number of tubers in $15^{\text {th }}$ and $30^{\text {th }}$ September planted crop were due to high temperature stress to potato crop which resulted in decreased tuberization and tuber production. Yield is ultimately determined by the rate and duration of tuber bulking and high temperature results in reduction of tuber yield or even failure of tuberization (Minhas et al., 2011).

\subsection{Yield of tubers}

Highest yield of small size tubers $\left(4.2 \mathrm{t} \mathrm{ha}^{-1}\right)$ was recorded with $30^{\text {th }}$ October planting window which was significantly higher with all other windows except $15^{\text {th }}$ October window. Production of medium size tubers $\left(11.9 \mathrm{t} \mathrm{ha}^{-1}\right)$ was highest with $15^{\text {th }}$ October window which was significantly higher over all other windows except $30^{\text {th }}$ October (Table 2). Highest production of large size tubers $\left(15.9 \mathrm{tha}^{-1}\right)$ was recorded with $15^{\text {th }}$ October window which was significantly higher over all other windows except $30^{\text {th }}$ October. Highest production (31.6 $\mathrm{t} \mathrm{ha}^{-1}$ ) of all size tubers was recorded with $15^{\text {th }}$ October planted crop which was significantly higher over all other treatments except $30^{\text {th }}$ October window. The rate and duration of bulking depends largely on canopy health and size, genotype, soil and air temperatures, the night to daytime temperature differential, day length and incident radiation (Minhas et al., 2011). 


\begin{tabular}{|c|c|c|c|c|c|c|c|c|c|c|c|c|c|}
\hline \multirow[b]{2}{*}{$\begin{array}{l}\text { Planting } \\
\text { windows }\end{array}$} & \multirow[t]{2}{*}{ LAI } & \multirow{2}{*}{$\begin{array}{l}\text { LFW } \\
\text { (g) }\end{array}$} & \multirow{2}{*}{$\begin{array}{l}\text { SFW } \\
(\mathrm{g})\end{array}$} & \multirow{2}{*}{$\begin{array}{c}\text { RFW } \\
(\mathrm{g})\end{array}$} & \multicolumn{4}{|c|}{ Number of tubers ha-1 } & \multicolumn{5}{|c|}{ Yield of tubers $\left(\mathrm{t} \mathrm{ha}^{-1}\right)$} \\
\hline & & & & & $\begin{array}{c}\text { Small } \\
(<25 \mathrm{~g})\end{array}$ & $\begin{array}{l}\text { Medium } \\
(25-75 \mathrm{~g})\end{array}$ & $\begin{array}{c}\text { large } \\
(>75 \mathrm{~g})\end{array}$ & $\begin{array}{c}\text { Total } \\
\text { (all size) }\end{array}$ & $\begin{array}{c}\text { Small } \\
\text { size } \\
\text { tubers }\end{array}$ & $\begin{array}{l}\text { Medium } \\
\text { size } \\
\text { tubers }\end{array}$ & $\begin{array}{c}\text { large } \\
\text { size } \\
\text { tubers }\end{array}$ & Total & BY \\
\hline $15^{\text {th }}$ Sep & 1.65 & 30.1 & 22.2 & 1.35 & 84,865 & 50,823 & 44,711 & $1,80,399$ & 1.9 & 3.7 & 5.8 & 11.4 & 14.5 \\
\hline $30^{\text {th }}$ Sep & 1.16 & 41.4 & 25.3 & 0.73 & 85,597 & 52,755 & 46,167 & $1,84,519$ & 1.9 & 6.0 & 8.2 & 16.1 & 18.8 \\
\hline $15^{\text {th }}$ Oct & 2.3 & 74 & 49.1 & 1.29 & 172,440 & 170,282 & 102,580 & $4,45,302$ & 3.8 & 11.9 & 15.9 & 31.6 & 34.3 \\
\hline $30^{\text {th }}$ Oct & 1.2 & 76.4 & 53.9 & 1.36 & 127,720 & 148,660 & 86,469 & $3,62,849$ & 4.2 & 10.7 & 14.4 & 29.3 & 31.3 \\
\hline $15^{\text {th }}$ Nov & 1.52 & 51.3 & 24.9 & 2.09 & 139,058 & 150,286 & 75,896 & $3,65,240$ & 3.0 & 9.9 & 10.5 & 23.4 & 25.4 \\
\hline $\operatorname{SEm} \pm$ & - & - & - & - & 16,344 & 9,726 & 4,301 & 19,402 & 0.43 & 0.59 & 2.33 & 2.14 & - \\
\hline $\begin{array}{l}\mathrm{CD} \\
(p=0.05)\end{array}$ & - & - & - & - & 35,615 & 21,193 & 9,372 & 42,277 & 0.95 & 1.30 & 5.08 & 4.66 & - \\
\hline
\end{tabular}

LAI: Leaf area index at 65 DAP; LFW: Leaf fresh weight ( $\left.\mathrm{g} \mathrm{plant}^{-1}\right)$; SFW: Stem fresh weight $\left(\mathrm{g} \mathrm{plant}^{-1}\right)$; RFW: Root fresh weight (g plant $\left.{ }^{-1}\right)$; BY: Biological yield

Higher night temperature above $20{ }^{\circ} \mathrm{C}$ in $15^{\text {th }}$ and $30^{\text {th }}$ September planting windows increased vegetative growth without converting carbohydrates into tubers (Basu and Minhas, 1991). Plants became tall and lanky.Stressed tuberizing potato plants alter in partitioning which results in reduced starch synthesis, increased sucrose level and reduced tuber dry matter(Levy et al 2013). Highest dry weight of haulms were recorded with $15^{\text {th }}$ September and $30^{\text {th }}$ September planted crop. Though biological yield was highest with $15^{\text {th }}$ October and $30^{\text {th }}$ October planted crop due to higher tuber yields. During second year late monsoon and winter rains increased mite damage however under dry conditions hopper burn was major insect in early planted crop.

\subsection{Economics}

Highest gross return of ₹ $1,89,187 \mathrm{ha}^{-1}$ was obtained with $15^{\text {th }}$ October planted crop which was significantly higher over all other treatments except $30^{\text {th }}$ October window (Table 3 ). Increase in income by planting at suitable dates results due to increased tuber yield by optimizing input efficiency (Ahmadi, 2008). Net return was highest with same treatment which was on par with $30^{\text {th }}$ October and $15^{\text {th }}$ November planting windows though other treatments gave negative returns. The negative returns were on account of lower yields due to higher temperatureand higher production costs. Higher cost of planting material (Azimuddin et al., 2009) and increased cost of cultural practices were main cause of high cost of potato cultivation. Similar trend was observed with B:C ratio also. Increasing temperature may cause potential threat to potato cultivation by increasing biotic and abiotic stresses and reducing input efficiency ultimately result in lower tuber yields (Rana et al., 2011).

\subsection{Fertility status of soil}

Significantly higher organic carbon was recorded with $30^{\text {th }}$ September planted crop which was significantly higher over all other treatments (Table 3). Higher organic carbon in $30^{\text {th }}$

Table 3: Economics and nutrient status of potato as influenced by planting windows (two years mean data)

\begin{tabular}{|c|c|c|c|c|c|c|c|c|c|}
\hline \multirow{2}{*}{$\begin{array}{l}\text { Planting } \\
\text { windows }\end{array}$} & \multicolumn{4}{|c|}{ Economics } & \multirow[t]{2}{*}{ OC (\%) } & \multirow{2}{*}{$\begin{array}{c}\text { Available } \\
\text { soil N } \\
\left(\mathrm{kg} \mathrm{ha}^{-1}\right)\end{array}$} & \multirow{2}{*}{$\begin{array}{c}\text { Tuber N } \\
\text { uptake } \\
\left(\mathrm{Kg} \mathrm{ha}^{-1}\right)\end{array}$} & \multirow{2}{*}{$\begin{array}{c}\text { NUE } \\
(\mathrm{kg} \text { tuber } \\
\left.\mathrm{kg}^{-1} \mathrm{~N}\right)\end{array}$} & \multirow{2}{*}{$\begin{array}{c}\text { WUE }(\mathrm{kg} \\
\text { tuber mm } \\
\left.\text { water }^{-1}\right)\end{array}$} \\
\hline & $\begin{array}{c}\text { Cost of } \\
\text { cultiva- } \\
\text { tion }\left(\text { ha }^{-1}\right)\end{array}$ & $\begin{array}{c}\text { Gross } \\
\text { return } \\
\left(\mathrm{ha}^{-1}\right) \\
\end{array}$ & $\begin{array}{l}\text { Net return } \\
\left(\mathrm{ha}^{-1}\right)\end{array}$ & $\mathrm{B}: \mathrm{C}$ ratio & & & & & \\
\hline $15^{\text {th }}$ September & 104,743 & 79,640 & (-) 43,085 & 0.76 & 0.35 & 326 & 33 & 63 & 33 \\
\hline $30^{\text {th }}$ September & 103,608 & 104,909 & (-) 2,005 & 1.0 & 0.46 & 295 & 47 & 90 & 54 \\
\hline $15^{\text {th }}$ October & 104,775 & 189,187 & 39,217 & 1.8 & 0.34 & 351 & 92 & 175 & 126 \\
\hline $30^{\text {th }}$ October & 104,300 & 161,221 & 14,982 & 1.54 & 0.40 & 408 & 86 & 163 & 117 \\
\hline $15^{\text {th }}$ November & 101,578 & 117000 & 15422 & 1.15 & 0.42 & 439 & 90 & 130 & 94 \\
\hline $\operatorname{SEm} \pm$ & - & 11,641 & 11,642 & 0.11 & 0.02 & 17 & 6 & 17 & 5 \\
\hline $\mathrm{CD}(p=0.05)$ & - & 35,368 & 25,368 & 0.25 & 0.04 & 36 & 14 & 37 & 11 \\
\hline
\end{tabular}

Sale rate of potato: $15^{\text {th }}$ September: ₹ $7 \mathrm{~kg}^{-1} ; 30^{\text {th }}$ September: ₹ $6.5 \mathrm{~kg}^{-1} ; 15^{\text {th }}$ October: ₹ $6 \mathrm{~kg}^{-1} ; 30^{\text {th }}$ October: ₹ $5.5 \mathrm{~kg}^{-1} ; 15^{\text {th }}$ November: ₹ $5 \mathrm{~kg}^{-1}$ 
September treatment might be due to lower removal of nutrients from soil.

Highest available $\mathrm{N}$ (439 $\left.\mathrm{kg} \mathrm{ha}^{-1}\right)$ was estimated with $15^{\text {th }}$ November planted crop which might be due to coverage of land by crop canopy for longer time which is known to maintain $\mathrm{N}$ availability for longer time by reducing $\mathrm{N}$ losses from soil.

\subsection{Nitrogen uptake and use efficiency}

Comparatively higher $\mathrm{N}$ uptake was recorded with $15^{\text {th }}$ October planted crop which was significantly higher over all other planting windows (Table 3). Higher uptake of $\mathrm{N}$ was attributed to favourable climatic condition resulting in higher tuber yield. Highest $\mathrm{N}$ use efficiency (175 kg tuber $\mathrm{kg}^{-1} \mathrm{~N}$ applied) was recorded with $15^{\text {th }}$ October planted crop which was significantly higher with all other planting windows except $30^{\text {th }}$ October.

\subsection{Water use efficiency}

Highest water use efficiency $\left(126 \mathrm{~kg}\right.$ tuber $\mathrm{mm}^{-1}$ of applied water) was recorded with $15^{\text {th }}$ October planted crop which was significantly higher over all other planting windows except $30^{\text {th }}$ October. A considerable increase in water application without significant increase in yield is known to reduce the water use efficiency (Kumar et al., 2006).

\section{Conclusion}

Preponding planting window is liable to reduce potato tuber yield drastically due to higher temperature unsuitable for tuberisation and bulking. Early planting needs special attention towards crop agronomy from weed management and protection of crop from mites and hoppers in the region. Management of plant growth to maximize yield and economic return while minimizing water, fertilizer, pesticides and other inputs is a primary goal in commercial crop production. Hence, most suitable planting date for the region is $15^{\text {th }}$ October.

\section{Acknowledgement}

We are thankful to Dr Sanjay Rawal, CPRIC, Meerut for providing facilities for chemical analysis of samples, $\mathrm{Mr}$ Sanjay Sharma, CPRS, Gwalior for assistance in conduct of experiment and chemical analysis. Mohammad, A., Hamad, R.J., Khan, E.A., Mohammad, R., 2005. Comparative response of diverse rice varieties to green manuring (Sesbania aculeata). Journal of Research (Science) 16, 39-43. Mortvedt, J.J.,
1979. Crop response to zinc sources applied alone or with suspensions. Fertilizer in Solution 23, 64-79.

\section{References}

Ahmadi, M.T., 2008. Estimating growth rates and decomposition analysis of agricultural production in Iran. Trends in Agricultural Economics 1(1), 14-26.

Azimuddin, M.D., Alam, Q.M., Baset, M.A., 2009. Potato for food security in Bangladesh. International Journal of Sustainable Crop Production 4(1), 94-99.

Hijmans, R.J., 2003. The effect of climate change on global potato production. American Journal Potato Research 80(4), 271-279.

Jaggard, K.W., Qi., A.M., Ober, E.S., 2010. Possible changes to arable crop yields by 2050. Philosophical transactions of the royal society of Londan, Series B: Biological Sciences 365, 2835-2851.

Basu, P.S., Minhas, J.S., 1991. Heat tolerance and assimilate transport in different potato genotypes. Journal of Experimental Botany 42, 56-66.

Knowles, N.R., Knowles, L.O., 2006. Manipulating stem number, tuber set, and yield relationships for northernand southern-grown potato seed lots. Crop Science 46, 284-296.

Kumar, S., Mandal, G., Asrey, R., Singh, R., 2006. Influence of irrigation and fertilization on yield, production efficiency and economic returns on drip irrigated potato under Semi arid environment. Potato Journal 33, 26-30.

Levy, D., Coleman, W.K., Veilleux, R.E., 2013. Adaptation of potato to water shortage:irrigation management and enhancement of tolerance to drought and salinity. American Journal Potato Research 90, 186-206.

Minhas, J.S., Rawat, S., Govindakrishnan, P.M., Kumar, D., 2011. Possibilities of enhancing potato production in non-traditional areas. Potato Journal 38(1), 13-17.

Pavek, M.J., Thornton, R.E., 2009. Planting depth influences potato plant morphology and economic value. American Journal Potato Research 86, 56-67.

Rana, R.K., Sharma, N., Kadian, M.S., Girish, B.H., Arya, S., Camplan, D., Pandey, S.K., Carlic, C., Patel, N.H., Singh, B.P., 2011. Perception of gujrat farmers on heat tolerant potato varieties. Potato Journal 38(2), 121-29. 